ABDI: Jurnal Pengabdian dan Pemberdayaan Masyarakat ISSN: 2656-369X (Print), 2684-8570 (Online)

Volume 3 No. 2, Desember 2021

http://abdi.ppj.unp.ac.id/index.php/abdi

Email: abdi@ppj.unp.ac.id

DOI: https://doi.org/10.24036/abdi.v3i2.123

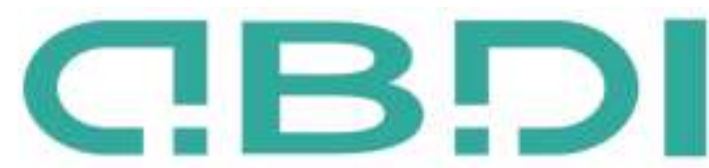

ABDt JURNAL PENGABDIN DAN PEMBERDAYAN MASYARAKAT

\title{
Penerapan Nilai Karakter Bagi Kaum Proletar Usia Remaja di Yayasan Kemah Kasih
}

\section{Sutrisno Sutrisno, ${ }^{1}$ Bobby Kurnia Putrawan, ${ }^{2}$ Christiani Hutabarat, ${ }^{3}$ Susanti Embong Bulan ${ }^{4}$}

\author{
${ }^{1,2}$ Sekolah Tinggi Teologi Moriah \\ ${ }^{3}$ Sekolah Tinggi Teologi Indonesia \\ ${ }^{4}$ Sekolah Tinggi Teologi Widya
}

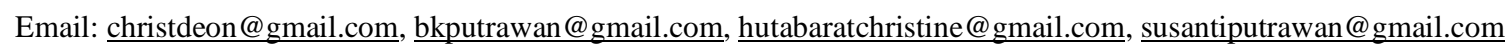

\begin{abstract}
Abstrak
Kegiatan pengabdian kepada masyarakat yang dilakukan ini bertujuan untuk meningkatkan nilai-nilai karakter kaum proletar usia remaja (12-17 Tahun) di Yayasan Kemah Kasih agar mereka menjadi pribadi yang lebih baik dan dapat diterima masyarakat dengan baik. Penyuluhan yang dilakukan dalam kegiatan ini adalah memberikan pendampingan dan pemahaman tentang penerapan nilai-nilai karakter yang harus dimiliki oleh kaum proletar usia remaja (12-17 Tahun). Model penyuluhan ini menggunakan penerapan nilai-nilai karakter. Hasil dari kegiatan pengabdian kepada masyarakat ini adalah dengan adanya penyuluhan yang dilakukan secara efektif dapat meningkatkan pemahaman dan kemampuan kaum proletar usia remaja (12-17 Tahun) perihal nilainilai dalam pendidikan karakter seperti menghargai keberagaman, memahami kekurangan dan kelebihan diri sendiri, menunjukkan sikap percaya diri, kemandirian, mematuhi aturan-aturan sosial yang berlaku di lingkungan dan menanamkan nila-nilai moral dapat mereka terapkan dalam hidup bermasyarakat.
\end{abstract}

Kata Kunci: Remaja Proletar, Nilai-Nilai Karakter, Penyuluhan.

\section{Abstract}

This community service activity aims to improve the character values of the proletarian youth (12-17 years) at the Kemah Kasih Foundation so that they become better individuals and can be well accepted by the community. The counseling carried out in this activity is to provide assistance and understanding of the application of character values that must be possessed by the proletarian youth (12-17 years). This extension model uses the application of character values. The result of this community service activity is that effective counseling can increase the understanding and ability of the proletarian youth (12-17 years old) regarding values in character education such as respecting diversity, understanding one's own strengths and weaknesses, showing an attitude self-confidence, independence, obeying social rules that apply in the environment and instilling moral values they can apply in social life.

Keywords: Character Values, Counseling, Proletarian Youth.

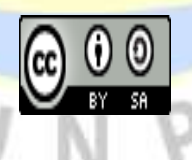

Received: 23 Juni $2021 \quad$ Revised: 10 Agustus $2021 \quad$ Available Online: 18 Agustus 2021


Sutrisno Sutrisno, Bobby Kurnia Putrawan, Christiani Hutabarat, Susanti Embong Bulan Penerapan Nilai-Nilai Karakter Bagi Kaum Proletar Usia Remaja di Yayasan Kemah Kasih

\section{Pendahuluan}

Karl Marx merujuk kata proletar untuk menunjukkan suatu kelas yang disebut sebagai kelas proletar. Kelas masyarakat ini sebenarnya sudah banyak muncul sebagai sebuah rujukan kelas dengan nama-nama yang berbeda. Dalam pemahaman Karl Marx proletar adalah masyarakat kelas dua setelah kelas kapitalis yang hidup dari gaji hasil kerjanya. Banyak asumsi yang memandang bahwa proletar hanya terbatas sebagai masyarakat kelas rendah. Pekerjaan mereka tak lepas dari buruh, petani, nelayan atau orang-orang yang berkutat dengan pekerjaan tangan (pekerjaan kasar) (Marta, 2017; Takdir, 2018).

Di Indonesia, terutama di Jawa era kolonial, masyarakat proletar dipegang oleh kaum pribumi. Mereka adalah orang yang paling tereksploitasi dalam era-era kolonial Hindia Belanda. Menurut peraturan yang dibuat pemerintah kolonial, mereka benar-benar dikurangi haknya sampai batas minimal. Jadi yang dimaksud kaum proletar adalah masyarakat kelas bawah yang hidup dari gaji hasil kerjanya (menjual tenaganya). Mereka adalah kaum pekerja yang hanya hidup selama mereka mendapat pekerjaan. Kaum proletar hanya terbatas sebagai masyarakat kelas rendah. Pekerjaan mereka tak lepas dari buruh bangunan, buruh tani, pembantu rumah tangga (buruh cuci-gosok), kuli, nelayan atau orang-orang yang berkutat dengan pekerjaan tangan (pekerjaan kasar), termasuk didalamnya remaja yang lahir dan hidup dalam keluarga dalam kondisi seperti disebut remaja proletar (Marta, 2017; Sumartono Mulyo Diharjo, 2019; Takdir, 2018).

Remaja proletar merupakan tunas bagi suatu bangsa. Lingkungan tempat dimana remaja proletar bertumbuh dan belajar saat ini ada yang memberikan pengaruh yang baik, namun ada pula yang memberikan pengaruh yang buruk. Untuk membantu membebaskan masyarakat dari kebodohan dan keterbelakangan yang mengakibatkan rendahnya kualitas sumber daya manusia, pendidikan memegang peranan yang sangat penting. Pendidikan merupakan kebutuhan mendasar dalam upaya meningkatkan kualitas sumber daya manusia. Hakikat pendidikan adalah sebuah proses transformasi ilmu yang bisa memanusiakan manusia (membuat hidupnya menjadi lebih baik), tetapi di zaman yang sangat "kapitalistik" pendidikan malah dijadikan seperti sebuah barang dagangan yang hanya bisa dibeli oleh orang-orang yang punya duit. Pendidikan seharusnya bisa dinikmati oleh seluruh masyarakat tanpa terkecuali. Tidak hanya sekedar gratis, tapi juga harus berkualitas, pendidikan juga haruslah ilmiah, sehingga para murid tidak hanya sekedar tahu "hasilnya", tapi juga tahu proses dari hasil tersebut (Nuraida, 2016; Sayektiningsih, Sumardjoko, \& Achmad, 2017).

Kurangnya peran keluarga dan pendidikan menyebabkan adanya indikasi masalah tawuran, sex bebas, narkoba, masih merajalela di kalangan usia remaja. Masalah diatas juga dialami oleh masyarakat perkotaan di daerah Pademangan Barat. Melihat fenomena ini, maka peneliti sangat tertarik berbagi sedikit ilmu bagaimana menerapkan nilai-nilai karakter kepeda mereka. Fakta yang sangat menyedihkan tentang epidemi narkotika menyerang remaja proletar setiap tingkatan sosial, setiap kota, setiap agama, setiap tingkat pendidikan-(Kent R. Brand \& D Charles Williams, 2018; Cahyati \& Azinar, 2011; Nurfalah, 2016). Oleh karena itu setiap orangtua dan pendidik harus wajib mendidik remaja proletar untuk menghindari dari hal yang bertentangan dengan nilai-nilai agama, karena remaja proletar merupakan generasi pewaris dan penerus pembangunan bangsa, baik buruknya pendidikan yang mereka terima dan alami akan turut menentukan baik buruknya kelangsungan warisan pembangunan yang ditinggalkan pendahulunya. Pendidikan sejak dini sesungguhnya tidak lain untuk menegaskan urgensi perhatian terhadap pendidikan remaja itu sendiri (Dewi, Degeng, \& Hadi, 2019; Hutabarat \& Putrawan, 2021; Nurfalah, 2016; Sutrisno \& Hutabarat, 2019). Dengan demikian betapa pentingnya pendidikan karakter sejak dini terhadap remaja-remaja proletar. Menurutnya, karakter adalah kualitas positif peduli, adil, jujur, hormat terhadap sesama dan bertanggung jawab (A. C. P. Harahap, 2019; Kesuma, 2011; Lewis, 2011; Sutrisno, Hestiningrum, Lumingkewas, \& Putrawan, 2021).

Guru atau pendidik memiliki tanggung jawab besar dalam menghasilkan generasi yang berkarakter, berbudaya, dan bermoral. Guru yang baik merupakan faktor utama dalam pendidikan, karena gurulah yang membimbing peserta didik untuk belajar, mengenal, memahami, dan

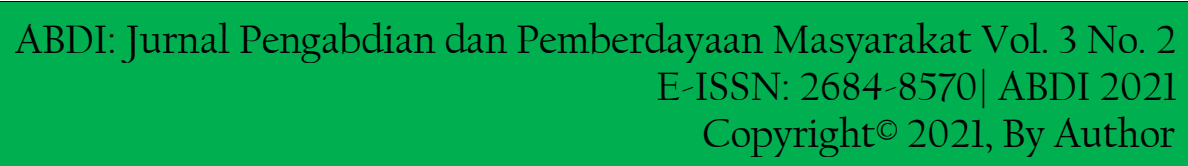


menghadapi dunia tempat ia berada (dunia ilmu pengetahuan dan teknologi, iman, karya dan dunia sosial budaya). Ada indikasi munculnya permasalahan kenalakan di usia remaja dipicu oleh kurangnya perhatian guru atau pendidik terhadap penerapan nilai-nilai moral (Dewi et al., 2019).

Dari penjelasan di atas dapat dikatakan bahwa pembentukan karakter seorang remaja proletar disamping dipengaruhi oleh pribadinya sendiri, juga dipengaruhi oleh faktor lingkungan, seperti sekolah, keluarga, masyarakat dan teman bermain, karena salah dalam bergaul akan mengakibatkan seorang remaja proletar tidak memiliki nilai-nilai moral dalam dirinya. Sehingga dengan adanya pendidikan karakter, budaya, dan moral, diharapkan bahwa tidak ada perkelahian antar suku, perkelahian antar agama, perkelahian antar tetangga yang hanya dibatasi oleh jalan raya. Adanya budaya malu untuk berbuat curang, malu menyontek, malu berbuat sesuatu kejahatan, malu untuk korupsi benar-benar tertanam di hati dan pikiran setiap manusia Indonesia (Aw, 2016; Hidayah, 2015).

Sangatlah menyedihkan apabila kita melihat remaja proletar sudah tidak memiliki sopan santun, kepedulian terhadap keadaan diri sendiri dan masyarakat disekelilingnya. Keberhasilan masa depan Indonesia tergantung bagaimana kita dapat mendidik remaja proletar bangsa agar menjadi remaja proletar yang peduli dan memiliki tanggung jawab moral untuk membangun negeri Indonesia tercinta.

Keberadaan dan terbentuknya keluarga tidak lepas dari suatu masyarakat. Keluarga merupakan unit dasar pembentuk masyarakat. Apabila kita membicarakan tentang suatu masyarakat, itu artinya kita sedang membicarakan sekumpulan keluarga dengan berbagai pola budaya keluarga-keluarga tersebut. Gejala masyarakat, konsep nilai yang ada dan semua pola tingkah lakunya, tidak lain merupakan manifestasi dari gejala, konsep nilai dan tingkah laku mayoritas keluarga yang membentuknya (Dewi et al., 2019; A. Harahap, 2018).

Fenomena remaja proletar jalanan itupun akhir-akhir ini semakin ramai di beberapa kota dan daerah, khususnya di pusat-pusat kota dan jalan-jalan raya yang mobilitas kendaraannya tinggi, dipasar-pasar tradisional, terminal antar kota/kecamatan. Remaja proletar ini harus kehilangan haknya untuk bersekolah dan bermain bersama teman sebayanya dengan penuh keceriaan dan kegembiraan selayaknya dunia remaja proletar, dan terpaksa harus pula meninggalkan cita-citanya dengan bekerja, karena orangtua mereka tidak mampu menanggung beban membiayai keperluan sekolah, membeli buku pelajaran, pakaian seragam dan yang lainnya (Widhyharto, 2014).

Remaja proletar dengan kondisi diatas juga dialami oleh remaja proletar di daerah Pademangan Barat. Tidak sedikit dari mereka yang terpaksa putus sekolah dan menjadi pengangguran dikarenakan keadaan ekonomi yang kurang. Remaja proletar miskin ini beresiko untuk bertumbuh sebagai orangorang yang berpendidikan rendah bahkan buta huruf sehingga kemungkinan besar mereka menjadi orang-orang miskin masa depan dan akan menjadi generasi yang hilang (lost generation) yang tidak pernah terlepas dari masalah seperti kekurangan gizi, pelacuran usia dini yang sangat rentan dengan HIV/AIDS serta tindak kriminalitas (Sumartono Mulyo Diharjo, 2019; Widhyharto, 2014).

Dalam hal ini maka dapat disimpulkan bahwa kesadaran perilaku sosial remaja proletar di pademangan barat masih rendah. Oleh karenanya penerapan nilai-nilai karakter perlu diberikan kepada remaja proletar tersebut, dengan itu kami harus memberikan penyuluhan yang tepat bagi remaja proletar di Pademangan Barat, Jakarta Utara. Melihat realita yang ada di lingkungan remaja proletar yang telah dijelaskan di atas, maka seharusnya kita sebagai warga bangsa bersama-sama terbeban untuk membentuk sebuah wadah pendidikan sosial, dimana di tempat ini berharap mereka dapat bertemu dengan kegiatan-kegiatan positif yang dapat membangun potensi mereka, dan yang akhirnya dapat membuahkan pengharapan yang baru bagi remaja proletar di masa depan.

Melihat permasalahan di atas, maka kegiatan pengabdian kepada masyarakat yang dilakukan sasarannya adalah bagi remaja proletar yang ada di kecamatan Pademangan Barat. Supaya penerapan yang hendak dicapai bisa terealisasi secara optimal, maka pendidik dan remaja proletar remaja di Pademangan Barat memahami beberapa nilai-nilai karakter. Maka dalam hal ini kami memberikan penerapan tentang karakter dan nilai-nilai karakter kepada mereka dalam hal menghargai keberagaman, menunjukkan sikap percaya diri, kemandirian, dan kerjasama. 
Sutrisno Sutrisno, Bobby Kurnia Putrawan, Christiani Hutabarat, Susanti Embong Bulan Penerapan Nilai-Nilai Karakter Bagi Kaum Proletar Usia Remaja di Yayasan Kemah Kasih

\section{Metode Pelaksanaan}

\subsection{Bentuk Kegiatan}

Kegiatan Pengabdian Kepada Masyarakat (P2M) di Pademangan Barat - Jakarta Utara, dilaksanakan pada tanggal 2, 9, 16, 23, 30 Januari dan 7 Februari 2021 bertempat di Yayasan Kemah Kasih. Kegiatan yang dilaksanakan meliputi penyuluhan tentang penerapan nilai-nilai karakter. Jumlah remaja proletar yang ikut adalah sejumlah 72 remaja proletar. Penyuluhan penerapan nilainilai karakter dilakukan melalui tahapan kegiatan, meliputi:

a. kegiatan Survei tempat P2M yaitu di Yayasan Kemah Kasih, salah satu yayasan yang ada di kecamatan Pademangan Barat.

b. permohonan Ijin kegiatan kepada Ketua RT: 14 dan Koordinator Yayasan Kemah Kasih

c. persiapan alat dan bahan serta akomodasi

d. persiapan tempat untuk penyuluhan P2M, yaitu menggunakan ruangan di Yayasan Kemah Kasih.

e. persiapan untuk tempat praktek simulasi penerapan nilai-nilai karakter.

\subsection{Sasaran}

Kegiatan penyuluhan penerapan nilai-nilai pendidikan karakter di yayasan Kemah Kasih pademanagn Jakarta Utara ini ditujukan pada remaja kaum proletar usia 12-17 tahun yang berjumlah 72 remaja proletar. Remaja yang mengikuti kegiatan ini semua beralamat di sekitaran Kecamatan Pademangan Barat, Jakarta Utara.

\section{Hasil dan Pembahasan}

\subsection{Kegiatan Penyuluhan}

Kegiatan Penyuluhan, meliputi:

\subsubsection{Pertemuan tanggal 2 Januari 2021,}

Pada pertemuan awal, peneliti tiba di Yayasan Kemah Kasih dan bertemu langsung dengan ketua dan koordinator yayasan ibu. Dr. Christiani Hutabarat. Kegiatan dilaksanakan pukul 10.00 WIB dengan di buka oleh Ketua Yayasan. Adapun kegiatan yang dilakukan antara lain:

1. Pembukaan dan kata sambutan dari ketua Yayasan Kemah Kasih: Ir. Puri Palupi.

2. Kata sambutan Koordinator Yayasan Kemah Kasih: Dr. Christiani Hutabarat, M.Pd.

3. Kata Sambutan dari ketua RT: 14: Bpk. Awaludin

4. Doa Pembuka Oleh Tokoh Pemuda Pademangan Barat: Bpk. Jarwo

5. Perkenalan peneliti kepada peserta yang hadir

6. Warna Sari

7. Rencana melanjutkan kegiatan praktek penerapan nilai karakter kepada penduduk setempet.

\subsubsection{Pertemuan tanggal 9 Januari 2021,}

Kegiatan pembekalan nilai-nilai karakter.

Adapun kegiatan yang dilakukan antara lain:

1. Pukul 8.40 Wib tiba di Yayasan Kemah Kasih

2. Pukul 9.00 Penyuluhan mengenai pengertian pendidikan karakter, dan penerapan nilai-nilai karakter bagi remaja proletar kaum proletar.

3. Sesi Diskusi/tanya jawab dengan peserta sesuai dengan pokok bahasan yang sudah dipaparkan oleh peneliti.

4. Warna Sari

5. Rencana melanjutkan kegiatan praktek penerapan nilai karakter kepada penduduk setempet 


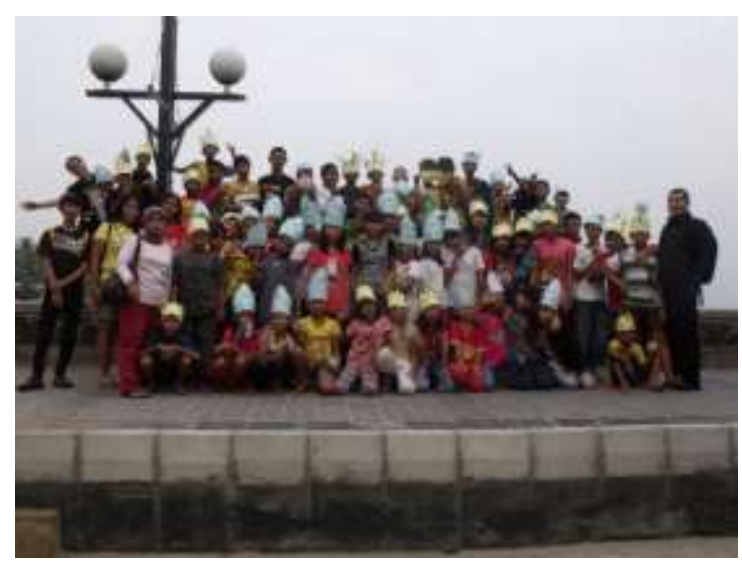

\section{Gambar 1. Pembukaan Kegiatan: dilaksanakan di Ancol (outdoor)}

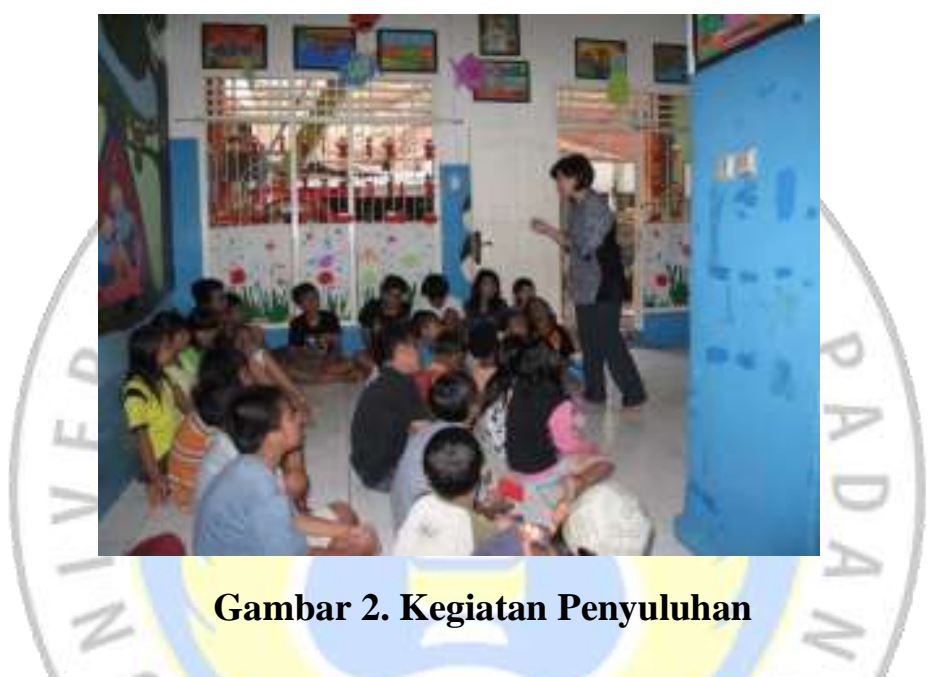

Penyuluhan mengenai penyampaian materi pengertian karakter, contoh-contoh karakter yang harus diteladani, dan setelah itu diadakan tanya jawab. Pada kegiatan ini dihadari oleh 31 remaja proletar. Materi tentang pengertian karakter dan contoh-contoh karakter disampaikan oleh Ir. Puri Palupi. Pada pertemuan ini pembelajaran masih terfokus penyampaian materi pada peserta. Pemahaman mereka tentang apa itu karakter dan apa saja contoh-contoh karakter, rata-rata baru 53\%. Karena sebelumnya tidak ada pelatihan terkait dengan karakter dan contoh-contoh karakter.

Setelah dipaparkan materi tentang pengertian karakter dan contoh-contoh karakter yang harus dimiliki peserta, para peserta tersebut semakin memahaminya. Narasumber memaparkan tentang pengertian karakter dan contoh-contoh karakter, dengan menggunakan permainan (game). Kegiatan Game yang dilakukan: Ketika pemimpin game mengatakan kata "Karakter" semua peserta harus berdiri, ketika mengatakan "Mengasihi Sesama", peserta harus membuat kelompok yang jumlahnya ditentukan pemimpin untuk per kelompoknya (yang kurang/lebih dari umlah yang ditentukan maka dinyatakan kalah dan tidak berlanjut dalam permainan), dan ketika pemimpin game mengatakan "Mandiri", semua harus berdiri sendiri-sendiri. Permainan ini dilakukan berulang-ulang sampai peserta game tinggal tersisa 3 orang, dan 3 orang yang tersisa tersebutlah pemenang permainan tersebut. Kemudian kegiatan ditutup dengan rencana kegiatan beberapa hari kedepan yang akan dilaksanakan di Yayasan Kemah Kasih.

Hasil yang didapat setelah mengikuti pelatihan pada tahap pertama tentang pengertian karakter dan contoh-contoh karakter adalah peserta dapat menyebutkan/hafal pengertian dan contohcontohnya.

$$
\begin{array}{r}
\text { ABDI: Jurnal Pengabdian dan Pemberdayaan Masyarakat Vol. } 3 \text { No. } 2 \\
\text { E-ISSN: 2684-8570| ABDI } 2021 \\
\text { Copyright }{ }^{\odot} \text { 2021, By Author }
\end{array}
$$


Sutrisno Sutrisno, Bobby Kurnia Putrawan, Christiani Hutabarat, Susanti Embong Bulan Penerapan Nilai-Nilai Karakter Bagi Kaum Proletar Usia Remaja di Yayasan Kemah Kasih

\subsubsection{Pertemuan tanggal 16 Januari 2021}

Kegiatan praktek penerapan nilai karakter ke- 1, yaitu: "menghargai keberagaman"

Penyuluhan yang dilakukan mengenai keragaman yang ada di indonesia, dan bagaimana kita menyikapi keragaman yang ada, agar kita sesama tetap terus dapat saling bergandengan tangan, meskipun berbeda. Kegiatan: remaja proletar diminta untuk mencari referensi pakaian adat (bisa di buku maupun google) dan kemudian mereka membuat pakaian adat dari beberapa daerah tersebut dengan bahan kertas koran, kemudian mereka diminta mempresentasikan di depan teman-teman mereka. Tujuan daripada aktifitas ini adalah peserta bisa mengenal keragaman budaya daerah yang ada di Indonesia. Hasil yang didapat setelah mengikuti pelatihan tahab ke dua tentang menghargai keberagaman adalah peserta semakin bertambah wawasannya mengenai keberagaman budaya yang ada di Indonesia dan mereka semakin saling menghargai satu dengan yang lain meskipun mereka beda suku dan agama.

\subsubsection{Pertemuan tanggal 23 Januari 2021}

Kegiatan praktek penerapan nilai karakter ke- 2, yaitu: "menunjukkan sikap percaya diri "

Penyuluhan yang dilakukan mengenai sikap percaya diri. Disini mereka diajarkan bagaimana mereka dapat menjadi pribadi yang tidak gampang minder/malu jika berhadapan dengan orang lain. Kegiatan: peserta diminta untuk membuat sebuah hasil karya, kemudian mereka mempresentasikan tentang karya yang mereka buat di depan teman-teman mereka, dan peserta lain boleh menanyakan tentang apa saja seputar karya tersebut.

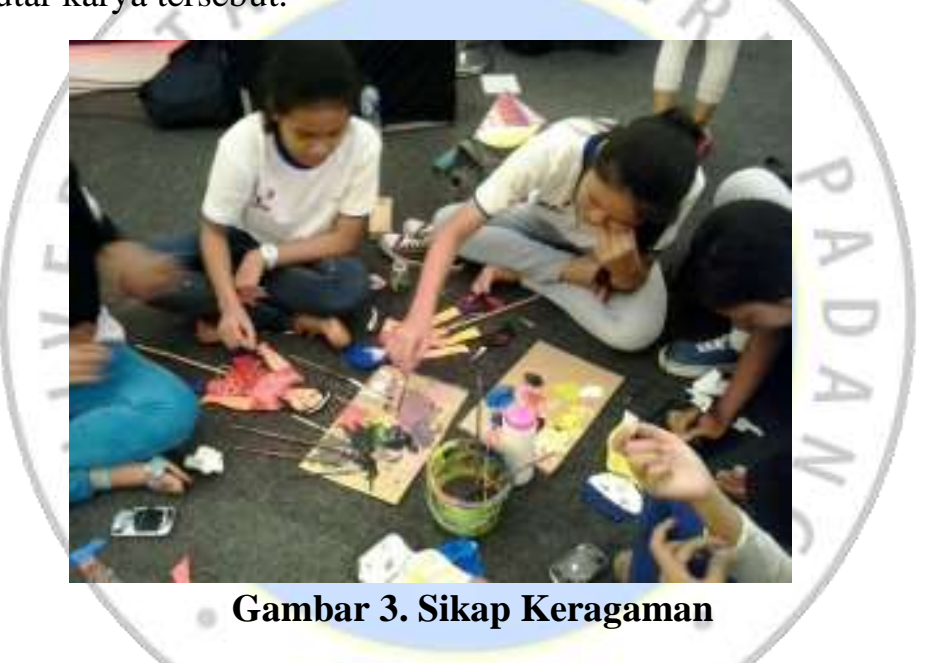

Tujuannya: mereka dapat percaya diri bicara didepan umum dan terlatih untuk bicara/berhadapan dengan banyak orang, dan melalui kegiatan ini, diharapkan dapat menambah/membentuk rasa percaya dirinya. Hasil yang didapat setelah mengikuti pelatihan tahab ketiga tentang sikap percaya diri adalah peserta semakin bertambah rasa percaya dirinya, perubahan tersebut terlihat ketika mereka berhasil menunjukkan bahwa mereka bisa membuat karya dari hasil tangannya, dan bahkan mereka tidak malu lagi berbicara didepan umum ketika mereka harus mempresentasikan didepan teman-temannya.

\subsubsection{Pertemuan tanggal 30 Januari 2021}

Kegiatan praktek penerapan nilai karakter ke- 3, yaitu: "Kemandirian".

Penyuluhan yang dilakukan mengenai karakter kemandirian. Dalam penyuluhan ini peserta diminta menerapkan karakter kemandirian bagaimana mereka dapat mengeluarkan ide sendiri dan menuangkan dalam bentuk karya gambar/lukisan. Kegiatan: remaja proletar diminta untuk membuat gambar/lukisan dengan ide sendiri (tidak boleh meniru ide temannya) dan mempersiapkan bahanbahan sendiri. Hasil yang didapat setelah mengikuti pelatihan tahab ke- empat tentang "kemandirian" adalah peserta mengerti apa itu kemandirian dan mereka juga berhasil menunjukkan bahwa mereka bisa berpikir dengan ide sendiri dan membuat karya sendiri tanpa harus mengandalkan orang lain.

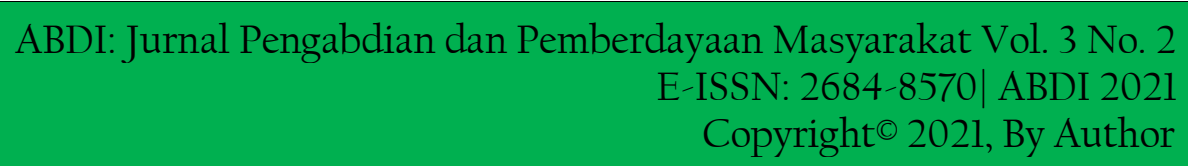




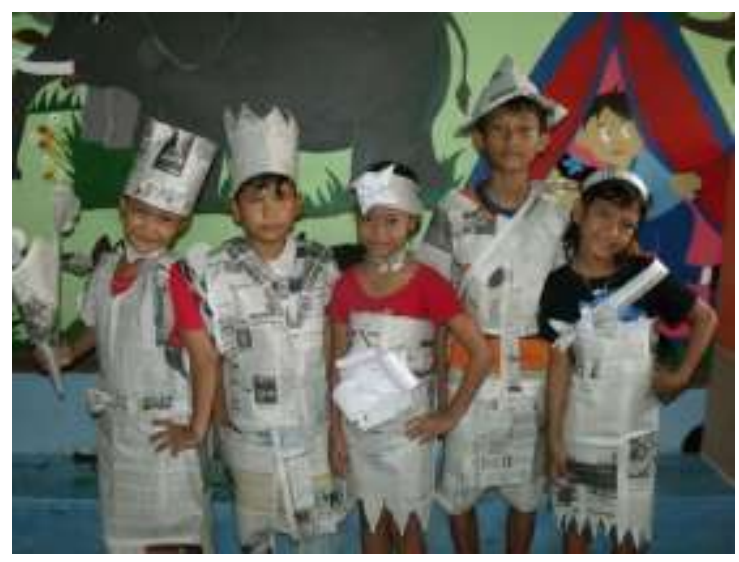

Gambar 4. Sikap Percaya Diri

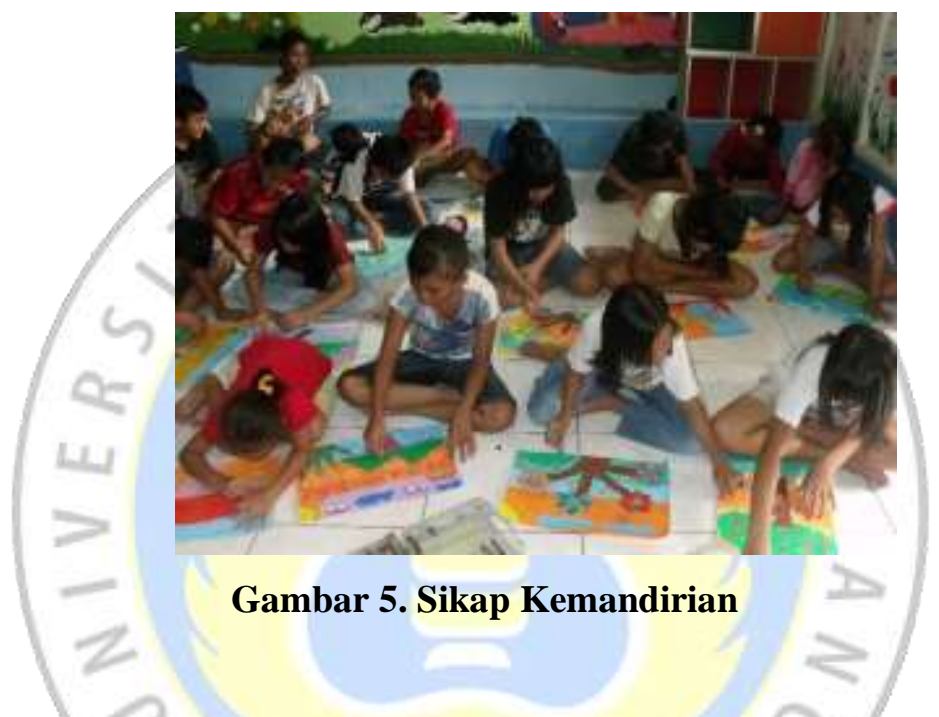

\subsubsection{Pertemuan tanggal 7 Februari 2021}

Kegiatan praktek penerapan nilai karakter ke- 4, yaitu: "Kerjasama/Gotong royong".

Penyuluhan yang dilakukan mengenai Kebersamaan/Gotong royong. Dalam penyuluhan kali ini bukan saja teori yang diberikan, melainkan peserta juga diminta langsung praktek turun kelapangan. Kegiatan: remaja proletar bersama-sama melaksanakan kebersamaan atau kegiatan gotong royong kerja bakti membersihkan sampah dan got di wilayah RT. 13, RT. 14 dan RT. 15.

Hasil yang didapat setelah mengikuti pelatihan tahab ke-lima tentang "Kebersamaan" adalah peserta mampu memahami dan mengerti apa itu makna kebersamaan, dan mereka juga secara langsung turun ke masyarakat untuk membantu membersihkan sampah yang ada dilingkungan mereka dengan menunjukkan kebersamaan sebagai keluarga. Karena mereka sudah mengerti ketika lingkungan menjadi bersih maka berimbas juga pada dirinya.

\subsubsection{Penutupan}

Pada bagian akhir dilakukan pemberian door prize bagi peserta yang mampu menjawab pertanyaan pada kegiatan penyuluhan, foto bersama dengan peserta, kunjungan ke beberapa lokasi dan gotongroyong membersihkan got (selokan), jalan dan sampah-sampah, dan pembuatan laporan kegiatan PKM dan disetujui oleh Ketua STT Moriah.

Untuk sesi penutupan, dilaksanakan kegiatan pemberian hadiah buat remaja proletar yang rajin datang dan dapat menjawab pertanyaan. 
Sutrisno Sutrisno, Bobby Kurnia Putrawan, Christiani Hutabarat, Susanti Embong Bulan Penerapan Nilai-Nilai Karakter Bagi Kaum Proletar Usia Remaja di Yayasan Kemah Kasih

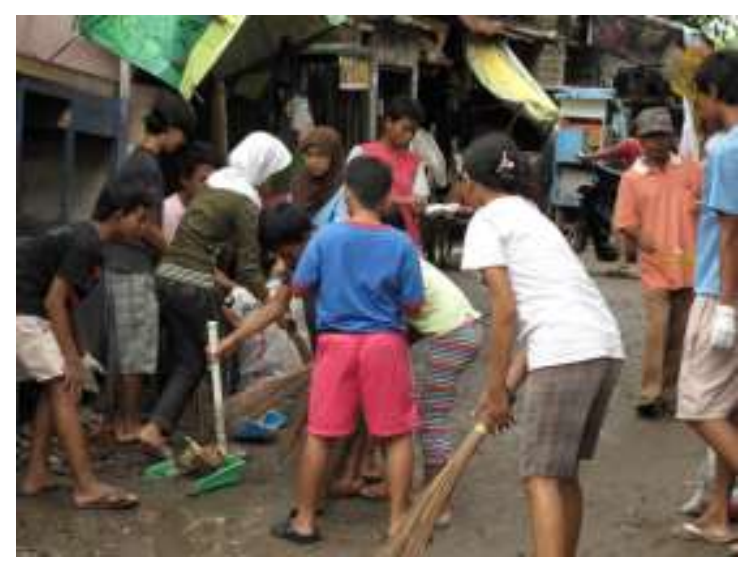

Gambar 5. Pembentukan sikap Kerjasama (Gotong Royong)

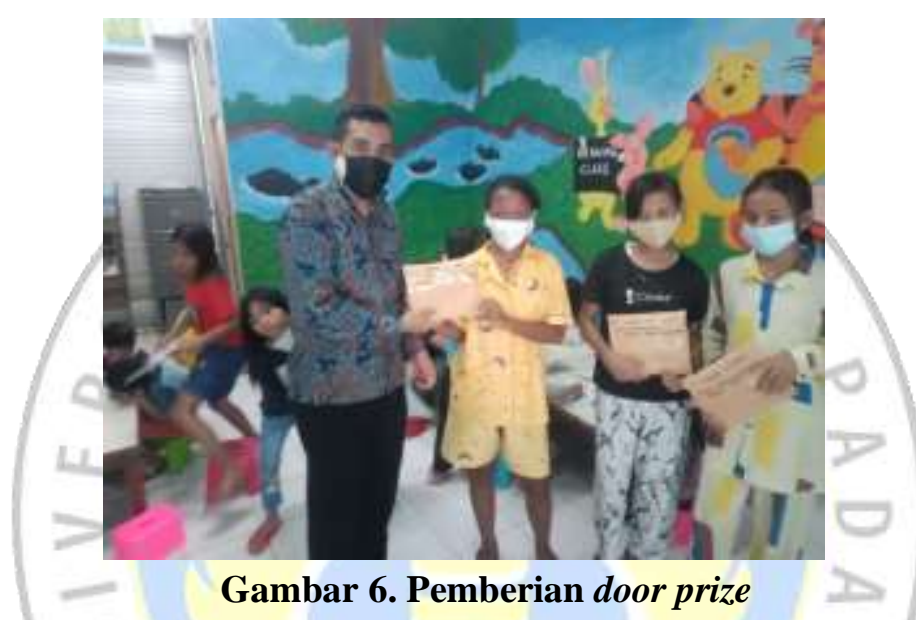

\subsection{Deskripsi Proses Kegiatan}

Kegiatan penyuluhan penerapan nilai-nilai karakter bagi kaum proletar usia remaja (12-17 tahun) yang dilaksanakan di Yayasan Kemah Kasih pada tanggal 2, 9, 16 dan 23 Januari 2021. Pada tanggal 2 Januari 2021 kegiatan pembukaan penyuluhan dilakukan di Ancol. Kegiatan dimulai dengan pembukaan PKM oleh ketua Yayasan Kemah Kasih: Ir. Puri Palupi. Kata sambutan oleh Koordinator Yayasan Kemah Kasih: Dr. Christiani Hutabarat, M.Pd dan ketua RT.14: Bpk. Awaludin, doa Pembuka Oleh Tokoh Pemuda Pademangan Barat: Bpk. Jarwo dan diikuti oleh 68 peserta.

Kegiatan pada tanggal 9, 16 dan 23 Januari 2021diikuti remaja proletar di Yayasan Kemah Kasih, Pademangan Barat, Jakarta Utara. Dalam penyuluhan tersebut rata-rata diikuti 42-68 peserta. Peserta, panitia dan pengurus Yayasan Kemah Kasih membantu mempersiapkan tempat bagi peneliti melakukan kegiatan PKM. Kegiatan PKM ini melibatkan remaja yang berdomisili di Jalan Budi Mulia Raya RT. 13, 14 dan 15 di RW 11, karena keberadaan Yayasan Kemah Kasih tersebut berada di RT. 14 RW. 11.

Dalam kegiatan ini, sebelum melakukan penyuluhan, pemateri memperkenalkan diri terlebih dahulu dan menjelaskan maksud serta tujuan dalam kegiatan ini. Serta menerangkan latar belakang peneliti melakukan kegiatan P2M. Sesuai dengan UU Republik Indonesia Nomor 14 Tahun 2005 Tentang Guru dan Dosen pasal 60 bagian a yaitu Dosen melaksanakan proletaran pendidikan, penelitian, dan pengabdian kepada masyarakat maka dosen wajib melakukan kegiatan P2M.

Kegiatan pemberian materi oleh peneliti berlangsung selama kurang lebih 2x60 menit. Kegiatan ini dipandu oleh Koordinator Yayasan Kemah Kasih: ibu. Dr. Christiani Hutabarat, M.Pd sebagai moderator pada acara inti.

\section{ABDI: Jurnal Pengabdian dan Pemberdayaan Masyarakat Vol. 3 No. 2


Peneliti menjelaskan materi penyuluhan penerapan nilai-nilai karakter menggunakan dengan Power Point. Peneliti sekaligus sebagai nara sumber menjelaskan dengan memberikan teori-teori dan beberapa video yang menunjang pembelajaran tersebut. Adapun materi yang peneliti paparkan yaitu pengertian karakter dan nilai-nilai karakter yang harus dimiliki oleh remaja dan diterapkan dalam pergaulan dan hidup bermasyarakat.

Aktifitas kegiatan penyuluhan tentang: 1. menghargai keberagaman : peserta diminta untuk membuat pakaian adat dari beberapa daerah dengan bahan kertas koran, kemudian mereka diminta mempresentasikan di depan teman-teman mereka. 2. Sikap percaya diri: peserta diminta untuk membuat sebuah hasil karya, kemudian mereka diminta mempresentasikan tentang karya yang mereka buat di depan teman-teman mereka, dan peserta lain boleh menanyakan tentang apa saja seputar karya tersebut. 3. Kerjasama (gotong royong): peserta bersama-sama melaksremaja proletaran kegiatan gotong royong kerja bakti membersihkan sampah dan got (selokan) di wilayah RT.13, RT.14 dan RT.15.

\subsection{Keberlanjutan Program}

Kegiatan penelitian, pengabdian kepada masyarakat tentang penyuluhan penerapan nilai-nilai karakter bagi kaum proletar usia remaja (12-17 tahun) yang dilakukan oleh Yayasan Kemah Kasih dan STT Moriah terlaksana dengan baik bahkan para peserta antusias mengikuti kegiatan ini dan mengharapkan dapat berlanjut dengan kegiatan-kegiatan berikutnya, karena mereka merasakan dampak positif yang bisa secara langsung mereka dapat terapkan di lingkungan mereka.

Pengabdian kepada masyarakat tidak hanya terfokus pada remaja proletar di wilayah pademangan barat, Jakarta Utara saja, tetapi juga dapat diterapkan di tempat-tempat yang lain.

\subsection{Analisis Pembahasan}

Hasil dari penyuluhan ini adalah penerapan nilai-nilai karakter yang dilakukan oleh remaja proletar di Yayasan Kemah Kasih, Pademangan Barat, Jakarta Utara berjalan secara efektif dalam meningkatkan karakter pada diri remaja proletar ini. Kegiatan ini merupakan bagian untuk meningkatkan dan mencerdaskan kehidupan bangsa (Tanasyah, Iswahyudi, \& Phang, 2020). Hal ini dapat dibuktikan sebagai berikut:

Pertama, remaja kaum proletar semakin bertambah pengetahuan atau wawasannya tentang keberagaman budaya yang ada di Indonesia dan mereka semakin saling menghargai satu dengan yang lain meskipun mereka beda suku dan agama. Tentu hal hal ini didasari teori bahwa meningkatnya pengetahuan atau wawasan yang benar dan baik, maka berdampak pada pembentukan karakter dan sikap remaja (Mellinda Fatimah, Abdulkarim, \& Iswandi, 2020; Onah \& Uroko, 2021).

Kedua, remaja kaum proletar semakin bertambah rasa percaya dirinya, perubahan tersebut terlihat ketika mereka berhasil menunjukkan bahwă mereka bisa membuat karya dari hasil tangannya, dan bahkan mereka tidak malu lagi berbicara di depan umum ketika mereka harus mempresentasikan di depan teman-temannya. Remaja proletar memiliki kecenderungan menempatkan dirinya pada tempat marjinal dan merasa rendah diri ketika berhadapan dengan orang lain yang dilihatnya berada pada strata sosial di atasnya. Penerapan pembimbingan contoh karakter percaya diri berdampak pada peningkatan rasa percaya diri pada remaja proletar (Bahabol \& Singal, 2020; Priyatni, 2013).

Ketiga, remaja kaum proletar mengerti apa itu kemandirian dan mereka juga berhasil menunjukkan bahwa mereka bisa berpikir dengan ide sendiri dan membuat karya sendiri tanpa harus mengandalkan orang lain. Karakter kemandirian menjadi satu bagian penting pada diri remaja proletar dalam mengembangkan diri untuk menjalani kehidupannya secara bertanggung jawab dengan cara mengelola dirinya, seperti mengelola waktu, bekerja, dan lain sebagainya (Nasution, 2018; Tanasyah \& Simanungkalit, 2020).

Keempat, remaja kaum proletar mampu memahami dan mengerti apa itu makna kebersamaan (gotong royong), dan mereka juga secara langsung turun ke masyarakat untuk membantu membersihkan sampah yang ada dilingkungan mereka dengan menunjukkan kebersamaan sebagai keluarga. Karakter kebersamaan menjadi bagian penting dalam bertumbuh dan kembangnya remaja proletar dari suatu proses internalisasi dalam dirinya. Karakter kebersamaan (gotong royong)

$$
\begin{array}{r}
\text { ABDI: Jurnal Pengabdian dan Pemberdayaan Masyarakat Vol. } 3 \text { No. } 2 \\
\text { E-ISSN: 2684-8570| ABDI } 2021 \\
\text { Copyright@ 2021, By Author }
\end{array}
$$


Sutrisno Sutrisno, Bobby Kurnia Putrawan, Christiani Hutabarat, Susanti Embong Bulan Penerapan Nilai-Nilai Karakter Bagi Kaum Proletar Usia Remaja di Yayasan Kemah Kasih

berdampak pada diri remaja proletar tidak menjadi seorang yang egois dan mementingkan dirinya sendiri. Dengan kata lain, karakter kemandirian ini memunculkan sikap kerendahhatian dan menghormati (menghargai) orang lain (Afryanto, 2012; Bahabol, 2019; Dewi et al., 2019).

Kelima, dengan dilakukannya penyuluhan, maka remaja kaum proletar dapat menjadi berkat buat lingkungan mereka tinggal, dengan ikut serta berperan aktif menjaga dan melestarikan lingkungan. Bertambahnya pengetahuan (wawasan) dan terwujudnya sikap percaya diri, kemandirian, dan kebersamaan memberikan dampak kesatuan dan kedamaian, dan berkembangnya bangsa Indonesia (August Cornelis Tamawiwy, 2021; Bahabol \& Singal, 2020; Wahyuni, Sri; Kadang, 2019).

\section{Kesimpulan}

Dari hasil kegiatan Penelitian dan Pengabdian Kepada Masyarakat yang dilakukan, kita dapat simpulkan beberapa hal, sebagai berikut: pertama, dengan dilakukannya penerapan, maka pemahaman remaja kaum proletar tentang pengertian karakter dapat meningkat. Kedua, dengan dilakukannya penerapan, maka remaja kaum proletar dapat memahami pokok-pokok bahasan seputar nilai-nilai karakter yang harus mereka terapkan dalam lingkungan masyarakat di mana mereka berada. Ketiga, dengan dilakukannya penerapan, maka remaja kaum proletar dapat menerapkan nilai-nilai karaktrer: menghargai keberagaman; sikap percaya diri, kemandirian dan kerjasama, baik itu dalam pergaulan di sekolah maupun dalam lingkungan masyarakat.

\section{Daftar Pustaka}

Afryanto, S. (2012). Internalisasi Nilai Kebersamaan melalui Pembelajaran Seni Gamelan (Pendidikan Karakter bagi Mahasiswa). Jurnal Seni \& Budaya Panggung, 23(1), 30-41. https://doi.org/10.26742/panggung.v23i1.85

August Cornelis Tamawiwy. (2021). A Foundation For a Culture of Justpeace: Church as a Hermeneutic Community to Promote Peace Narratives. MAHABBAH: Journal of Religion and Education, 2(1), 61-72. https://doi.org/https://doi.org/10.47135/mahabbah.v2i1.3

Aw, S. (2016). Nilai-Nilai Pendidikan Karakter Yang Terkandung Dalam Tayangan "Mario Teguh Golden Ways". Jurnal Pendidikan Karakter, 6(2), 181-191. https://doi.org/10.21831/jpk.v6i2. 12048

Bahabol, E. (2019). Plurality of Religion in Christian Views and The Implications for Christian Religious Education. Quaerens: Journal of Theology and Christianity Studies, 1(1), 61-81. https://doi.org/https://doi.org/10.46362/quaerens.v1i1.23

Bahabol, E., \& Singal, Y. (2020). Mendidik Untuk Kehidupan Berdasarkan Kompetensi Guru Kristen di Indonesia. Quaerens: Journal of Theology and Christianity Studies, 2(1), 62-85. https://doi.org/10.46362/quaerens.v2i1.21

Brand, K. R., \& Williams, D. C. (2018). Delapan Masalah Orangtua dan Anak. Jakarta: BPK Gunung Mulia.

Cahyati, W. H., \& Azinar, M. (2011). Peningkatan Pengetahuan dan Sikap Tentang Kesehatan Reproduksi Pada Remaja di Desa Margosari Kecamatan Limbangan Kabupaten Kendal. Jurnal Abdimas, 15(2), 110-115.

Dewi, A. K. T., Degeng, I. N. S., \& Hadi, S. (2019). Implementasi Pendidikan Nilai Karakter di Sekolah Dasar Melalui Budaya Sekolah. Jurnal Pendidikan: Teori, Penelitian Dan Pengembangan, 4(2), 247-255. https://doi.org/http://dx.doi.org/10.17977/jptpp.v4i2.12011

Harahap, A. (2018). Implementasi Nilai-Nilai Karakter dalam Pembelajaran Tematik Kelas III SD IT Darul Hasan Padangsidimpuan. Abdau: Jurnal Pendidikan Madrasah Ibtidaiyah, 1(1), 18-36. https://doi.org/10.36768/abdau.v1i1.3

Harahap, A. C. P. (2019). Pendidikan Karakter. Jurnal Pendidikan dan Konseling, 9(1), 1-11. Retrieved from http://jurnal.uinsu.ac.id/index.php/al-irsyad/article/view/6732/0 
Sutrisno Sutrisno, Bobby Kurnia Putrawan, Christiani Hutabarat, Susanti Embong Bulan Penerapan Nilai-Nilai Karakter Bagi Kaum Proletar Usia Remaja di Yayasan Kemah Kasih

Hidayah, N. (2015). Penanaman Nilai-nilai Karakter dalam Pembelajaran Bahasa Indonesia di Sekolah Dasar. Jurnal Pendidikan dan Pembelajaran Dasar, 2(2), 190-204. https://doi.org/https://doi.org/10.24042/terampil.v2i2.1291

Hutabarat, C., \& Putrawan, B. K. (2021). Pengantar Pola Asuh Orang tua dalam Keluarga Kristen. PNEUMATIKOS: Jurnal Teologi Kependetaan, 11(2), 84-94. Retrieved from https://stapin.ac.id/e-journal/index.php/pneumatikos/article/view/28

Kesuma, D. (2011). Pendidikan Karakter. Jakarta: Temprina Media Grafika.

Lewis, B. A. (2011). Character Building untuk Anak-Anak. Batam: Karisma Publishing.

Marta, R. F. (2017). Esensi dan Pemetaan Teoretisasi Media Komunikasi Dalam Perspektif Karl Marx. Bricolage: Jurnal Magister Ilmu Komunikasi, 2(2), 117-123. https://doi.org/10.30813/ bricolage.v2i02.839

Mellinda Fatimah, M., Abdulkarim, A., \& Iswandi, D. (2020). Increasing Students Understanding of National Insights Through Digital Literacy in Civic Education Learning. Jurnal Civicus, 20(1), 31-39.

Nasution, T. (2018). Kemandirian, Siswa dan Pendidikan Karakter. Ijtimaiyah, 2(1), 1-18.

Nuraida, N. (2016). Pengembangan Nilai-Nilai Karakter Melalui Pendidikan Pencak Silat Untuk Anak usia Dini (Studi Kasus di Paguron Pencak Silat Galura Panglipur Bandung). Tunas Siliwangi: Jurnal Program Studi Pendidikan Guru PAUD STKIP Siliwangi Bandung, 2(1), 2677. https://doi.org/https://doi.org/10.33367/tribakti.v27i1.264

Nurfalah, Y. (2016). Urgensi Nilai-Nilai Pendidikan Karakter. Jurnal Pemikiran Keislaman, 27(1), 170-187. https://doi.org/10.33367/tribakti.v27i1.264

Onah, N. G., \& Uroko, F. (2021). Hate Speech and Ethno-Religious Conflicts In Nigeria: Implications For Political Stability. MAHABBAH: Journal of Religion and Education, 2(2), 9294. https://doi.org/10.47135/mahabbah.v2i2.31

Priyatni, E. T. (2013). Internalisasi Karakter Percaya Diri dengan Teknik Scaffolding. Jurnal Pendidikan Karakter, 3(2), 164-173. https://doi.org/10.21831/jpk.v2i2.1437

Sayektiningsih, Sumardjoko, B., \& Achmad, M. (2017). Penanaman Nilai-Nilai Karakter dalam Pembelajaran Pendidikan Pancasila di Madrasah Aliyah Muhammadiyah Klaten. Jurnal Manajemen Pendidikan, 12(2), 228-238. https://doi.org/doi.org/10.23917/jmp.v12i3.5518

Sumartono Mulyo Diharjo. (2019). Dinamika Perubahan Sosial dalam Teori Konflik. Jurnal Ilmu Komunikasi Dan Bisnis, 5(1), 1-17. https://doi.org/http://dx.doi.org/10.36914/jikb.v5i1.259

Sutrisno, Hestiningrum, P., Lumingkewas, M. S., \& Putrawan, B. K. (2021). Christian Religious Education Toward The Teenagers Character Building. Evangelikal: Jurnal Teologi Injili Dan Pembinaan Warga Jemaat, 5(2), 202-212. https://doi.org/https://doi.org/10.46445/ejti.v5i2.330

Sutrisno, \& Hutabarat, C. (2019). Orang Tua dan Teman Bermain terhadap Perkembangan Sosial Anak. QUAERENS: Journal of Theology and Christianity Studies, 1(1), 28-55. https://doi.org/https://doi.org/10.46362/quaerens.v1i1.15

Takdir, M. (2018). Transformasi Kesetaraan Buruh: Studi Kritis Teori Keadilan John Rawls. Jurnal Sosiologi Reflektif, 12(2), 327. https://doi.org/10.14421/jsr.v12i2.1430

Tanasyah, Y., Iswahyudi, \& Phang, S. (2020). Membangun Kepemimpinan Kristen Entrepreneurial Sebagai Landasan Keberhasilan Upaya Memimpin. Quaerens: Journal of Theology and Christianity Studies, 2(2), 127-146. https://doi.org/10.46362/quaerens.v2i1.1

Tanasyah, Y., \& Simanungkalit, L. N. (2020). Perumpamaan Sebagai Model Pembelajaran Yang Efektif Untuk Proses Belajar Mengajar Pendidikan Kristen. Quaerens, 2(1), 30-43. https://doi.org/10.46362/quaerens.v2i1.18

Wahyuni, Sri; Kadang, Y. K. (2019). Mendidikan Anak. Quaerens: Journal of Theology and Christianity Studies, 1(2), 122-143. https://doi.org/10.46362/quaerens.v1i2.6

Widhyharto, D. S. (2014). Kebangkitan Kaum Muda dan Media Baru. Jurnal Studi Pemuda, 3(2), 141-146. Retrieved from https://journal.ugm.ac.id/jurnalpemuda/article/viewFile/32030/19354 